\title{
EFEKTIVITAS TERAPI AUDIO MUROTAL SURAH AR- RAHMAN TERHADAP PERUBAHAN TEKANAN DARAH PADA LANSIA DENGAN HIPERTENSI DI POSKESDES KEDUNGARUM UPTD PKM KUNINGAN KAB. KUNINGAN JAWA BARAT TAHUN 2016
}

The Effectiveness of Therapy Audio Murotal Surah Ar-Rahman On Changes In Blood Pressure With Hypertension For The Elderly In Poskesdes Kedungarum UPTD PKM Kabupaten Kab. Kuningan West Java 2016

\author{
Yana Hendriana \\ Fakultas IImu Keperawatan, STIKes Kuningan \\ E-mail: hendrianayana@rocketmail.com
}

\begin{abstract}
Abstrak
Pendahuluan: Resiko terkena hipertensi akan semakin meningkat, terutama pada lansia. Jika hipertensi pada lansia tidak dapat dikendalikan akan dapat menyebabkan komplikasi. Salah satu terapi komplementer yang dapat mengendalikan tekanan darah adalah terapi audio murotal surah Ar-Rahman. Tujuan: Dengan tujuan untuk mengetahui pengaruh terhadap perubahan tekanan darah pada lansia penderita hipertensi. Metode: Desain penelitian kuantitatif dengan metode quasi-eksperimental dengan rancangan one group pretest posttest design tanpa adanya kelompok kontrol. Jumlah sampel 39 responden dengan teknik Purposive Sampling. Analisa menggunakan uji Wilcoxon pada tekanan darah sistolik dan diastolik. Hasil: Uji statistik dengan uji Wilcoxon didapatkan bahwa nilai $p$ tekanan darah sistolik sebelum dan setelah diberikan terapi audio murotal surah Ar-Rahman adalah 0,025 dan nilai $p$ diastolik 0,180. Diskusi: Ada pengaruh terapi murotal surah Ar-Rahman terhadap perubahan tekanan darah sistolik.
\end{abstract}

Kata kunci: Lansia hipertensi, terapi audio murotal surah Ar-Rahman.

\begin{abstract}
Introduction: The risk of hypertension will increase, especially for elderly. If the hypertension of elderly is not controlled can lead to complications. One of the complementary therapy that can control blood pressure is audio Murottal therapy Ar-Rahman. Purpose: To know blood pressure changes of the elderly with hypertension. Method: A QuasyExperimental method of quantitative research design with one group pretest posttest design without a control group. Total sample in 39 respondents with NonProbability Sampling technique that is chosen by Purposive Sampling method. Analysis used the Wilcoxon test on systolic blood pressure and on diastolic blood pressure. Results: The results of the statistical test using the Wilcoxon test showed that systolic blood pressure $p$ value before and after the audio murottal therapy ArRahman is 0.025 and the test results $p$ value diastolic is 0.180 . Discussion: There murottal therapeutic effect surah Ar-Rahman of the blood pressure before and after a given intervention and no effect of the diastolic.
\end{abstract}

Keywords: Murrotal Therapy Ar-Rahman, Hypertension for The Elderly
JURNAL

SKOLASTIK

KEPERAWATAN

Vol, 5, No. 1

Januari - Juni 2019

ISSN: $2443-0935$

E-ISSN 2443 - 16990 


\section{PENDAHULUAN}

Sampai saat ini hipertensi atau yang lebih dikenal dengan tekanan darah tinggi masih menjadi masalah yang cukup penting dalam pelayanan kesehatan di dunia, baik di Negara maju maupun negara berkembang, termasuk di Indonesia. Data dari WHO (2010) menyatakan bahwa hipertensi merupakan penyakit nomor sebelas penyebab kematian tertinggi di dunia yaitu sebanyak 1.153.308 jiwa.

Hipertensi merupakan salah satu penyakit paling mematikan di dunia. Sebanyak 1 milyar orang di dunia atau 1 dari 4 orang dewasa menderita penyakit ini. Hipertensi secara tidak langsung membunuh penderitanya, melainkan memicu terjadinya penyakit lain yang tergolong kelas berat dan mematikan serta memberi gejala yang berlanjut untuk organ tubuh, seperti stroke untuk otak, penyakit jantung koroner untuk pembuluh darah dan otot jantung

(Korneliani dan Meida, 2012).

Berdasarkan data Kementrian Kesehatan Republik Indonesia (2013) jumlah penderita hipertensi di Indonesia mencapai 17-21\%dari jumlah penduduk 250 juta jiwa dan merupakan penyebab kematian urutan ketiga setelah stroke dan tuberculosis, yaitu mencapai $6,7 \%$ dari populasi kematian semua umur di Indonesia.

Berdasarkan laporan 10 besar penyakit rawat jalan seksi kesehatan khusus dan rujukan bidang pelayanan kesehatan Dinas Kesehatan Kuningan tahun 2015, menyatakan bahwa angka kejadian hipertensi berjumlah 8.018 orang dari total penduduk umur 55 tahun keatas sebanyak 183.584 jiwa. Data dari Poskesdes Kedungarum wilayah kerja UPTD PKM Kuningan Kuningan dari bulan Januari s.d. Mei 2016 bahwa penderita hipertensi pada lansia sebanyak 65 .

Hipertensi perlu mendapatkan terapi hipertensi yang dikelompokkan dalam terapi farmakologi dan terapi nonfarmakologi. Selain upaya tersebut, ada suatu upaya pengobatan yang termasuk dalam terapi nonfarmakologi yaitu terapi komplementer (pelengkap) yang bisa mempercepat proses penyembuhan. Ada beberapa terapi komplementer yang murah dan mudah serta dapat menurunkan tekanan darah pada pasien hipertensi, antara lain terapi

Tertawa, Teknik Relaksasi Otot Progresif, Aromaterapi. Namun, belum banyak yang mengetahui bahwa terapi Murottal Surah Ar-Rahman juga dapat menurunkan tekanan darah pada pasien hipertensi. Terapi Murottal Surah ArRahman ini juga merupakan terapi tanpa efek samping yang aman dan mudah dilakukan Mayrani dan Hartati, (2013).

Lantunan Al-Qur'an secara fisik mengandung unsur suara manusia, suara manusia merupakan instrument penyembuhan yang menakjubkan dan alat yang paling mudah dijangkau. Suara dapat menurunkan hormonhormon stres, mengaktifkan hormon endorphin alami, meningkatkan perasaan rileks, dan mengalihkan perhatian dari rasa takut, cemas dan tegang, memperbaiki sistem kimia tubuh sehingga menurunkan tekanan darah serta memperlambat pernafasan, detak jantung, denyut nadi dan aktivitas gelombang otak (Siswantinah, 2011).

Dari hasil riset beberapa peneliti yang meneliti dengan masing-masing terapi maka perlu dilakukannya penelitian 
tentang efektivitas terapi audio murotal surah Ar-Rahman terhadap perubahan tekanan darah pada lansia dengan hipertensi di Poskesdes Kedungarum UPTD PKM Kuningan Kab. Kuningan Jawa Barat.

\section{METODE}

Penelitian ini merupakan penelitian eksperimen semu (quasi experiment) dengan desain pre test and post test non equivalen tcontrol group.

Sebelum perlakuan dilakukan pengukuran awal (pre test) untuk menentukan tekanan darah responden sebelum perlakuan. Setelah perlakuan dilakukan pengukuran akhir (post test) untuk menentukan efek perlakuan pada responden.

Populasi yang diteliti adalah semua lansia dengan hipertensi di Poskesdes Kedungarum UPTD PKM Kuningan Kabupaten Kuningan Jawa Barat.

Sampel penelitian diperoleh dari populasi dengan cara pengambilan sampel secara purpossive sampling, yaitu pengambilan sampel yang didasarkan pada suatu pertimbangan tertentu yang dibuat oleh peneliti sendiri, berdasarkan ciri atau sifat-sifat populasi yang sudah diketahui sebelumnya. (Notoatmojo, 2010)

Berdasarkan data dari Poskesdes Kedungarum dari bulan Januari s.d Mei 2016 bahwa hipertensi pada lansia presenium dan senium berjumlah 65 orang, jumlah populasi yang terbatas ini (kurang dari 10.000 orang), maka peneliti menentukan jumlah sampel yang digunakan dalam penelitian ini dihitung dengan menggunakan rumus Notoadmodjo:

$$
n=\frac{\mathrm{N}}{1+\mathrm{N} \cdot \mathrm{d}^{2}}
$$

Berdasarkan rumus diatas dengan besar populasi 65 kasus di Poskesdes Kedungarum di peroleh besar sampel sebanyak 39,39 responden dibulatkan menjadi 39 responden.

Analisa univariat bertujuan untuk menjelaskan karakteristik setiap variabel penelitian (variabel bebas dan variabel terkait) (Notoadmodjo, 2010). Analisis ini dilakukan untuk memberikan gambaran deskriptif penelitian yang terdiri dari usia, jenis kelamin, riwayat hipertensi dan pekerjaan, yang disajikan dalam bentuk mean, nilai min-max, standar deviasi, dan CI 95\%.

Uji yang digunakan pada analisis bivariat adalah uji Wilcoxon matched pairs, karena hasil uji normalitas pada penelitian ini didapatkan $P$ value < 0,05 .

Tabel 1 Distribusi Karakteristik Responden Berdasarkan Usia

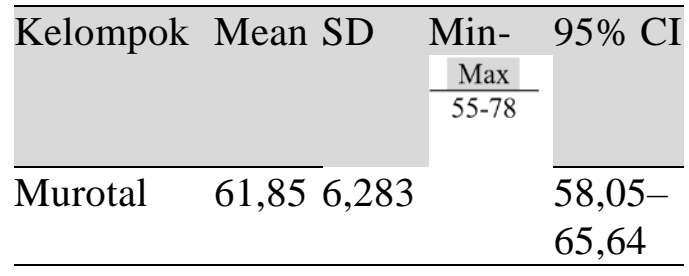

Hasil analisis dari tabel 5.1 didapatkan rata-rata usia responden lansia dengan hipertensi yang mendapatkan terapi audio murotal surah Ar-Rahman adalah 61,85 tahun. (95\% CI: 58,05 - 65,64) dengan standar deviasi 6,285 tahun. Usia termuda 55 tahun dan tertua 78 tahun. Dari hasil estimasi dapat disimpulkan bahwa $95 \%$ diyakini bahwa rata-rata usia responden lansia 
dengan hipertensi yang mendapatkan terapi murotal surah ArRahman adalah $58,05-65,64$ tahun.

Tabel 2 Distribusi Karakteristik Responden Berdasarkan Jenis Kelamin, Riwayat Hipertensi, dan Pekerjaan

\begin{tabular}{lcc}
\hline $\begin{array}{l}\text { Jenis } \\
\text { Kelamin }\end{array}$ & Murotal & $\%$ \\
\hline Laki-laki & 15 & 38,5 \\
\hline Perempuan & 24 & 61,5 \\
\hline Total & 39 & 100 \\
\hline $\begin{array}{c}\text { Riwayat } \\
\text { HT }\end{array}$ & Murotal & $\%$ \\
\hline Ya & 27 & 69.2 \\
\hline Tidak & 12 & 30,8 \\
\hline Total & 39 & 100 \\
\hline $\begin{array}{l}\text { Status } \\
\text { Pekerjaan }\end{array}$ & Murotal & $\%$ \\
\hline Bekerja & 21 & 53,8 \\
\hline $\begin{array}{l}\text { Tidak } \\
\text { Bekerja }\end{array}$ & 18 & 46,2 \\
\hline Total & 39 & 100 \\
\hline
\end{tabular}

Distribusi responden lansia dengan hipertensi pada masing-masing kelompok berdasarkan jenis kelamin paling banyak adalah perempuan yaitu yang mendapat terapi audio murotal surah Ar-Rahman 24 orang $(61,5 \%)$.

Distribusi responden lansia dengan hipertensi masing-masing kelompok mempunyai riwayat hipertensi yang mendapatkan terapi audio murotal surah Ar-Rahman sebanyak 27 orang $(69,2 \%)$.

Distribusi responden lansia hipertensi yang bekerja dan mendapatkan terapi audio murotal surah Ar-Rahman yaitu sebanyak 21 orang $(53,8 \%)$, baik pada.

Tabel 3 Hasil analisa pengaruh terapi audio murotal surah Ar-
Rahman, terapi audio musik tradisional degung sunda serta terapi gabungan audio murotal surahArRahman dan degung sunda

Tekanan Darah Sistol

\begin{tabular}{llll}
\hline Sebelum & 39 & 1,38 & 1,77 \\
\hline Sesudah & 0,599 & 0,506 & 0,025 \\
\hline \multicolumn{4}{l}{ Tekanan Darah Diastol }
\end{tabular}

\begin{tabular}{llll}
\hline Sebelum & 39 & 1,15 & 1,38 \\
\hline Sesudah & 0,376 & 0,180 & 0,768 \\
\hline
\end{tabular}

Berdasarkan hasil tabel 5.2 menunjukkan rata-rata tekanan darah sistol sebelum diberikan terapi audio murotal surah ArRahman adalah 1,77 dengan standar deviasi 0,599, dan setelah diberikan terapi diperoleh ratarata tekanan darah sistol adalah 1,38 dengan standar deviasi 0,506.

Dari hasil uji wilcoxon didapatkan $P$ value $0,025 \quad(\mathrm{P}<0,05)$, berarti ada pengaruh terapi murotal surah ArRahman terhadap perubahan tekanan darah sistol pada lansia dengan hipertensi sebelum dan sesudah terapi. Sedangkan rata-rata tekanan darah diastol sebelum diberikan terapi murotal surah ArRahman adalah 1,15 dengan standar deviasi 0,376, dan setelah diberikan terapi diperoleh ratarata tekanan darah diastol adalah 1,38 dengan standar deviasi 0,768 .

Dari hasil uji wilcoxon didapatkan $P$ value $0,180(\mathrm{P}>0,05)$, berarti tidak ada pengaruh terapi murotal surah ArRahman terhadap perubahan tekanan darah diastol pada lansia dengan hipertensi sebelum dan sesudah terapi. 
Tabel 4 Distribusi Perbedaan RataRata Perubahan Tekanan Darah Sistolik/ Diastolik Sebelum dan Sesudah Terapi

\begin{tabular}{llllll}
\hline $\begin{array}{l}\text { Kelomp } \\
\text { ok }\end{array}$ & $\begin{array}{l}\text { TD } \\
\text { sebelu } \\
\text { m }\end{array}$ & $\begin{array}{l}\text { Std } \\
.\end{array}$ & $\begin{array}{l}\text { TD } \\
\text { sesud } \\
\text { ah }\end{array}$ & $\begin{array}{l}\text { Std } \\
\text { Dev }\end{array}$ & $\begin{array}{l}\text { P valu } \\
e\end{array}$ \\
\hline Sistol & 1,77 & 0,59 & 1,38 & 0,50 & 0,02 \\
& & 9 & & 6 & 5 \\
\hline Diastol & 1,15 & 0,37 & 1,38 & 0,76 & 0,18 \\
& & 6 & & 8 & 0 \\
\hline
\end{tabular}

Dari tabel 5.3 di atas terdapat perbedaan rata-rata perubahan tekanan darah sistolik pada kelompok terapi audio murotal surah Ar-Rahman sebelum dilakukan terapi yaitu 1,77 dengan standar deviasi 0,599 dan sesudah terapi 1,38 dengan standar deviasi 0,506. Sedangkan perbedaan rata-rata perubahan tekanan darah diastolik terapi audio murotal surah ArRahman sebelum dilakukan terapi yaitu 1,15 dengan standar deviasi 0,376 dan sesudah terapi 1,38 dengan standar deviasi 0,768 ,

\section{PEMBAHASAN}

Responden dalam penelitian pada kelompok terapi audio murotal surah ArRahman didapatkan responden berusia antara 55 tahun sampai dengan 78 tahun.

Hal ini sesuai dengan pernyataan Anggraini, dkk (2009) bahwa setelah umur 45 tahun dinding arteri mengalami penebalan karena adanya penumpukan zat-zat kolagen pada lapisan otot pembuluh darah sehingga pembuluh darah akan berangsurangsur menyempit dan menjadi kaku. Hal ini sejalan dengan pernyataan Puspita dan Haskas (2014) yang menyatakan individu yang berumur diatas 60 tahun, 50-60\% mempunyai tekanan darah lebih besar atau sama dengan 140/90 mmHg. Hal itu merupakan pengaruh degenerasi yang terjadi pada orang yang bertambah usia.

Jenis kelamin pada penelitian didapatkan terbanyak adalah perempuan yaitu 24 orang $(61,5 \%)$.

Hasil survei kesehatan rumah tangga tahun 1995 menunjukkan prevalensi penyakit hipertensi atau tekanan darah tinggi di Indonesia cukup tinggi, yaitu 83 per 1.000 anggota rumah tangga. Pada umumnya lebih banyak pria menderita hipertensi dibandingkan dengan perempuan. Wanita $>$ pria pada usia > 50 tahun sedangkan pria > wanita pada usia

$<50$ tahun. (Muhammadun, 2010)

Menurut Udjianti (2011) efek perlindungan estrogen dianggap sebagai penjelasan adanya imunitas wanita pada usia premenopause. Pada premenopause wanita mulai kehilangan sedikit demi sedikit hormon estrogen yang selama ini melindungi pembuluh darah dari kerusakan. Proses ini terus berlanjut dimana hormon estrogen tersebut berubah kuantitasnya sesuai dengan umur wanita secara alami, yang umumnya mulai terjadi pada wanita umur 45-55 tahun. Hal ini yang mengakibatkan wanita pasca menopause beresiko tinggi untuk mengalami hipertensi.

Pada penelitian ini yang mempunyai riwayat hipertensi pada kelompok terapi audio murotal surah Ar-Rahman adalah 27 orang $(69,2 \%)$.

Menurut Puspita dan Haskas (2014) bahwa hipertensi bersifat diturunkan atau bersifat genetik. Individu dengan riwayat keluarga hipertensi mempunyai risiko dua kali lebih besar untuk menderita hipertensi dari pada 
orang yang tidak mempunyai keluarga dengan riwayat hipertensi. Hal ini sejalan dengan pernyataan Muhammadun (2010) bahwa para pakar juga menemukan hubungan antara riwayat keluarga penderita hipertensi (genetik) dengan resiko bagi orang yang menderita penyakit ini.

Pada penelitian ini status pekerjaan responden adalah kegiatan sehari-hari responden yang menghasilkan upah untuk memenuhi kebutuhan seharihari. Rata-rata responden memiliki status bekerja. Pada kelompok terapi audio murotal surah Ar-Rahman didapatkan responden yang bekerja 21 orang $(53,8 \%)$

Menurut Muhammadun (2010) Stress pada pekerjaan cenderung menyebabkan terjadinya hipertensi berat. Pria yang mengalami pekerjaan penuh tekanan, misalnya penyandang jabatan yang menuntut tanggung jawab besar tanpa disertai wewenang pengambilan keputusan, akan mengalami tekanan darah yang lebih tinggi selama jam kerjanya, dibandingkan dengan rekan mereka yang jabatannya lebih longgar tanggung jawabnya.

Perbedaan tekanan darah sistol dan diastole sebelum dan sesudah dilakukan dengan uji non parametric dengan uji wilcoxon. Penelitian ini menunjukkan bahwa terdapat perbedaan yang signifikan antara ratarata tekanan darah sistol sebelum dan sesudah diberikan terapi audio murotal surah Ar-Rahman. Secara statistik pada penelitian ini, perubahan tekanan darah sistol sebelum diberikan terapi audio murotal surah Ar-Rahman adalah 1,77, dan sesudah diberikan terapi audio murotal surah Ar-Rahman rata-rata tekanan darah sistol adalah 1,38. Hasil analisis menunjukkan $P$ value 0,025 $(\mathrm{P}<0,05)$. Sehingga disimpulkan bahwa ada pengaruh terapi audio murotal surah Ar-Rahman terhadap perubahan tekanan darah sistol pada lansia dengan hipertensi sebelum dan sesudah terapi. Sedangkan pada tekanan darah diastol menunjukkan bahwa rata-rata tekanan darah diastol sebelum diberikan terapi audio murotal surah Ar-Rahman adalah 1,15, dan sesudah diberikan terapi audio murotal surah Ar-Rahman rata-rata tekanan darah diastol adalah 1,38. Hasil analisis menunjukkan $P$ value $0,180(\mathrm{P}>0,05)$, sehingga disimpulkan bahwa tidak ada pengaruh terapi audio murotal surah ArRahman terhadap perubahan tekanan darah diastol pada lansia dengan hipertensi sebelum dan sesudah terapi.

Dari uraian diatas dapat disimpulkan bahwa pada perubahan tekanan darah sistolik setelah diberikan terapi audio murotal surah Ar-Rahman sejalan dengan penelitian yang dilakukan oleh Ernawati (2013) bahwa terjadi penurunan tekanan darah sistolik setelah diberikan terapi murotal surah Ar-Rahman, tetapi untuk perubahan tekanan diastolik setelah diberikan terapi audio murotal surah ArRahman tidak sejalan.

Sebagian dari keterangan responden yang diberikan terapi mengatakan bahwa setelah mendengarkan terapi audio murotal surah Ar-Rahman ini mereka merasakan tenang dan rilek tetapi sebagian lainya mengatakan biasa-biasa saja. Hasil penelitian ini sesuai dengan yang di kemukakan Heru (2008) bahwa lantunan Al-qur'an secara fisik mengandung unsur suara manusia, sedangkan suara manusia merupakan instrumen penyembuhan 
yang menakjubkan dan alat yang paling mudah dijangkau. Suara dapat menurunkan hormon-hormon endofrin alami, meningkat perasaan rileks, mengalihkan perhatian, rasa takut, cemas dan tegang, memperbaiki sistem kimia tubuh sehingga menurunkan tekanan darah serta memperlambat pernafasan, detak jantung, denyut nadi, dan aktivitas gelombang otak.

Terdapat perbedaan rata-rata perubahan tekanan darah sistolik pada kelompok murotal surah Ar-Rahman sebelum dilakukan terapi yaitu 1,77 dengan standar deviasi 0,599 dan sesudah terapi 1,38 dengan standar deviasi 0,506,

Sedangkan perbedaan rata-rata perubahan tekanan darah diastolik pada kelompok murotal surah Ar-Rahman sebelum dilakukan terapi yaitu 1,15 dengan standar deviasi 0,376 dan sesudah terapi 1,38 dengan standar deviasi 0,768 ,

\section{PENUTUP}

Karakteristik lansia dengan hipertensi yang mendapatkan terapi audio murotal surah Ar-Rahman berupa usia, jenis kelamin, riwayat hipertensi, dan status pekerjaan. Rata-rata usia responden adalah 61,85 tahun, sebagian besar berjenis kelamin perempuan, mempunyai riwayat hipertensi, dan sebagian besar masih bekerja.

Berdasarkan kesimpulan dari ketiga kelompok di atas di dapatkan hasil sebagai berikut:

1. Ada pengaruh terapi audio murotal surah Ar-Rahman terhadap perubahan tekanan darah sistol pada lansia dengan hipertensi.
2. Tidak ada pengaruh terapi audio murotal surah Ar-Rahman terhadap perubahan tekanan darah diastol pada lansia dengan hipertensi.

\section{DAFTAR PUSTAKA}

Abdurahman A., Perdana S. \& Andhika S. (2008).

Muratal Al

Qur'an: Alternatif suara baru. Prosiding Seminar Nasional Sains dan Tehnologi - II 2008

Universitas Lampung. ISBN: 978-

979-1165-74-79

Akhmad Sudrajat. (2008). Pengertian pendekatan, strategi, metode, teknik dan model pembelajaran. Bandung: Sinar Baru Algensindo.

Angkowo, Robertus dan A. Kosasih. (2007). Optimalisasi media pembelajaran. Jakarta. Grasindo

Arsayd, Azhari. (2009). Media pembelajaran. Jakarta: PT. RajaGrafindo Persada.

Aronow, W. S. (2013). Hypertensionrelated stroke prevention in the elderly. Current

Hypertension Report, 15(6), 582-589.

Astuti, D. (2009). Lagu dan alat musik tradisional Provinsi Jawa Barat. Bandung: Sarana Panca Karya

Nusa

Badriah, D.L. (2012). Ilmu-ilmu kesehatan masyarakat, ilmu kesehatan, 
ilmu keperawatan, ilmu keolahragaan. Bandung:

Multazam.

Bandiyah, (2009). Lanjut usia dan keperawatan gerontik. Yogyakarta: Nuha Medika

Banoe, P. (2003). Kamus musik. Yogyakarta

Bassano, Marry (2009) Terapi musik dan warna. Yogyakarta: Rumpun

Darmojo, B. (2009). Teori proses menua. In: H. Hadi Martono dan Kris Pranarka (eds): Buku Ajar Boedhi-Darmojo GERIATRI Edisi 4. Jakarta: Balai Penerbit FKUI, pp.3

Dinas Kesehatan Kab. Kuningan (2015). Laporan 10 Besar Penyakit Rawat Jalan: Seksi Kesehatan Khusus Dan Rujukan Bidang Pelayanan Kesehatan. Dinkes Kuningan 2015.

Ernawati. (2013). Pengaruh mendengarkan Murottal q.s ArRahman terhadap pola tekanan darah pada pasien hipertensi di rumah sakit Nur Hidayah Yogyakarta. Universitas

Muhammadiyah Yogyakarta.

Fadhlina, A. (2010). Perbandingan perubahan tekanan darah dan laju nadi antara pemberian petidin dan fentanil sebagai premedikasi anestesi ( http://eprints.uns.ac.id/8516/. Diakses : 21 Maret 2016, pukul $13.30 \mathrm{WIB})$.
Fauzi, I. (2014). Buku pintar deteksi dini gejala, \& pengobatan asam urat, diabetes \& hipertensi. Yogyakarta: Araska.

Feriyadi. (2012).

Pengaruh musik terhadap kesehatan jiwa, kerja dan otak manusia. Di unduh Maret 2016

Green dan Hertin, (2004). Terapi alternatif. Yogyakarta: Yayasan Spiritia

Hartati, (2011).

Perbedaan tekanan darah tenaga kerja sebelum dan sesudah terpapar kebisingan melebihi NAB Di Unit Boiler Batubara PT. Indo Acidatma, Tbk.

Kemiri, Kebakkramat, Karanganyar. ( http://eprints.uns.ac.id/7921/. Diakses : 20 Maret 2016, pukul 22.12 WIB).

Herawati, S. (2008). Seni budaya untuk sekolah menengah kejuruan. Jakarta: Departemen Pendidikan

Nasional

Herlambang. (2014). Menaklukan hipertensi \& diabetes mendeteksi, mencegah dan mengobati dengan cara medis dan herbal.

Publisher Jakarta: Tugu

Heru, (2008). Ruqyah syar'i berdasarkan kearifan lokal. Jakarta: PT Dian Rakyat. 
Kementrian Kesehatan Republik Indonesia (2013). Penyajian Pokok-Pokok Hasil Riset

Kesehatan Dasar 2013. Jakarta: Badan Litbangkes, Kemenkes $\mathrm{RI}$,

2013.http://depkes.go.id/downl oad /riskesdas2013/Hasi1\%20Riskes das \%202013.pdf

Korneliani, K. \& Meida, D. (2012). Hubungan obesitas dan stress dengan kejadian hipertensi guru sd wanita. 2012. Semarang. Jurnal

Kesehatan Masyarakat KEMAS,7(2):111-

115.http://journal.unnes.ac.id/nj u/i ndex.php/ kemas/article/view/1769/1968

Lestari. (2012). Laporan analisis jurnal A randomized controlled trial of the effect of musik therapy and verbal relaxion on chemoteraphy induced anxiety. Diunduh Maret 2016

Lingga, L. (2012). Bebas hipertensi tanpa obat. Jakarta. Agro Media Pustaka.

Martha Raile Alligood. (2014). Nursing theorist and their work eight edition. St Louis: Mosby Elsevier, Inc

Maryam. Dkk. 2008. Mengenal usia lanjut dan perawatannya. $\underline{\text { Salemba Medika: Jakarta }}$

Mayrani, E.D. dan Hartati, E. (2013). Intervensi terapi audio dengan murottal surah ar-rahman terhadap perilaku anak autis. Jurnal Keperawatan. Soedirman, 8(2), 69-76.

Muhammadun. (2010). Hidup bersama hipertensi. Yogyakarta. In Books.

Mustafiza PV. (2010). Hubungan antara hiperurisemia dengan hipertensi. Fakultas kedokteran universitas sebelas maret surakarta. Skripsi. Diambil tanggal 08 Maret 2016

Muttaqin, A. (2010). Pengkajian keperawatan. Jakarta: Salemba Medika.

Notoatmodjo, S. (2010). Metodologi penelitian kesehatan. Jakarta: Rineka Cipta.

Orem, D.E (2001). Nursing: Concepts of practice ( $\sigma^{\text {th }}$ ed., $p$ 491). St. Louis: Mosby

Pandoe. (2006). Musik terapi. Diakses $\underline{\text { maret } 2016}$

Polit, D.F., \& Beck, C.T. (2008). Nursing research: Generating and assesing evidence for nursing practice. Philadelphia: Lippincott.

Potter, Patricia A. (2005). Buku ajar fundamental keperawatan. Alih bahasa, Yasmin Asih ... [et al]; editor edisi Bahasa Indonesia, Devi Yulianti, Monica Ester. ed 4 -, Jakarta: EGC.

Puspita, E dan Haskas, Y. (2014). Faktor risiko kejadian hipertensi pada pasien yang berobat di Poliklinik Rumah 
Sakit Umum Daerah Labuang Baji Makasar.

Jurnal Ilmiah Kesehatan, 5(1), 58-64.

Saing S.K. (2007). Pengaruh musik klasik terhadap penurunan tekanan darah. USU-Fakultas Kedokteran

Santoso, H, (2009). Memahami krisis lanjut usia uraian medis dan pedagogis patoral. Gunung Mulia Cetakan I Jakarta.

Sastroasmoro, S., \& Ismael, S. (2011). Dasar-dasar metodelogi penelitian klinis, edisi 4. Jakarta: Sagung Seto.

Shimamoto. (2006). Chinese hypertension society. New York:

Delmar Publisher Inc

Siswantinah. (2011). Pengaruh terapi murottal terhadap kecemasan pasien gagal ginjal kronik yang dilakukan tindakan hemodialisa di

RSUD Kraton Kabupaten Pekalongan. Universitas Muhammadiyah Semarang (Skripsi).

Stefanus, K. (2011). Pengaruh terapi musik terhadap tingkat depresi pada lansia di Panti Werda Hanna. Diakses maret 2016

Sugiyono. (2014). Statistika untuk penelitian. Bandung: Alfabeta

Suherly, M., Ismonah., Meikawati, W. (2011). Perbedaan tekanan darah pada pasien hipertensi sebelum dan sesudah pemberian terapi musik klasik di rsud tugurejo Semarang., http://www.ejournal.sti kestelogorejo.ac.id Diakses pada tanggal 7 April 2015.

Suryana, D. (2006). Terapi musik. Yogyakarta

Susilo, Y. \& Wulandari, A. (2010). Cara jitu mengatasi hipertensi. Yogyakarta ANDI Yogyakarta.

Syafiq. (2003). Ensiklopedia musik klasik. Universitas Michigan: Adicita

Sylvia. (2009). Diet sehat untuk penyakit asam urat, diabetes, hipertensi dan stroke. Yogyakarta. A-Plus Books.

Udjianti, W.J. (2011). Keperawatan kardiovaskuler. Jakarta: Salemba Medika

Zuraidah, Maksuk, Apriliadi. (2012). Analisis faktor resiko penyakit hipertensi pada masyarakat di kecamatan kemuning kota palembang tahun 2012. Poltekes Palembang. Skripsi. Diambil tanggal

08 Maret 2016 